Ionornis martinica in Arizona.-About October 20, I887, a Chinaman caught a feinale Purple Gallinule in his vegetable garden on the Santa Cruz bottom opposite Tucson. He gave it to a Mexican boy from whom I purchased it ten days later. The bird was in good plumage, but its wings and tail were somewhat cage-worn. Length, Ir.50 inches; extent, $2 \mathrm{I}$; wing, 6.8o; tail, 2.72; tarsus, 2.25 . This, so far as I can learn, is the first of its kind ever taken in Arizona.-Herbert Brown, Tucson, Arizona.

Habits of the Purple Gallinule (Ionornis martinica).-While spending the spring and summer of 1887 at Yemassee, S. C., I found the Purple Gallinule to be the most common and characteristic of the birds breeding there. The locality where I found them was an old rice plantation of about six or seven hundred acres. This abandoned rice plantation is used as a reservoir, or, in local parlance, a 'backwater.' It is kept filled with water, to flow the rice of adjoining fields, and is usually covered with water to thè depth of three to four feet. The whole 'backwater' is overgrown with rushes, the broad-leafed pond lily (Nymphaa odorata) and the Nelumbium (Cyamus flavicomus). I found the Gallinules very common-there must have been at least five hundred pairs of birds. It was a very beautiful sight to see the graceful creatures walking over the large leaves of the pond lily, every now and then flirting their tails, or holding their wings over their heads, as they walked from one leaf to another. When flying, chasing one another, the legs are always hanging down. and the birds are cackling the whole time while engaged in this sport. They have several very peculiar call-notes, one which is very guttural, is to be heard incessantly. They are exceedingly tame-one can almost step on them before they take wing. If wounded they dive immediately, and remain under water for fully five minutes at a time, and it is folly to waste time in following them up, as they rise with only the point of the bill out of water. The soft parts in life are as follows:-Crown shield, azure blue, legs bright yeilow, the tip of bill greenish yellow, and the middle of bill bright red.

The nests are commenced about May 5. They are built in rushes, invariably over water, and are made of half decayed rushes. The nest is substantially built, and well secured to the rushes which grow in the water. The birds have regular trodden paths leading to their nests, and, strange to say, there are always three or four nests in all stages of completion near each nest which contains eggs. The eggs are from four to nine, almost invariably six. They measure about $1.60 \times$ I.15 inches, and are pale cream color or yellowish, spotted with brown or purplish. They vary in size and markings; some of the eggs I collected are larger than typical specimens of the Fiorida Gallinule, and some as small as large specimens of the Virginia Rail. I never saw a Gallinule sitting-day or night, rain or shine-and I really beleve the eggs are hatched by the decomposition of the materials which com $_{1}$ ose the nest. The young can 
easily be raised, and become perfectly tame. The breeding season is a long one, as I had a very young bird in the downy stage sent me alive on September I7. Its appearance is as follows: Upperparts glossy black, the lower parts sooty, the throat, cheeks, and top of head with silvery white hairs. The base of bill is yellowish, the lower mandible, and part of upper jet blackwith a white spot, which rises to a point on the tip of upper mandible ; this white spot resembles 'white lead.' The wings are also covered with silvery hairs.-Arthur T. WAYNE, Charleston, S. C.

\section{Unexpected Occurrence of Certain Shore Birds in Texas in Midsummer and in Breeding Plumage.-}

Macrorhamphus griseus. Dowitcher. - June I I, two adults, $\delta$ and $q$, in full breeding plumage, and two immature birds in the act of moulting or changing from winter to summer dress.

Macropalama himantopus. Stilt SAndpiper.-July 3, one adult female in breeding plumage.

Tringa canutus. KNoт.-July I, $q$; July 3 , $\delta$; July Io, $q$; all adults in full breeding plumage.

Totanus melanoleucus. Greater Yellow-Legs.-June I3, $\delta$; July 3 , + ; both adults in full breeding plumage.

Charadrius squatarola. Black-Bellied Plover.-July i, one adult male in nearly full breeding dress. On May I2, I882, I took at same place an adult male in full breeding plumage.

All of the above were taken at Corpus Christi, Texas, in 1887 , by my collector. Egialitis nivosa, Snowy Plover, breeds there and is not uncommon; large series of adults and young were secured. Five males, six females, and one immature bird changing to breeding plumage, of Arenaria interpres, Turnstone, were sent me, and any number could be taken in July. The adults were in as fine dress as if taken in Labrador. This confirms the observations of Dr. J. C. Merrill and myself during the last ten years. No eggs were secured, but that the bird breeds there can hardly admit of a doubt.-Geo. B. Sennetr, Am. Mus. Nat. Hist., New York City.

The European Kestrel in Massachusetts. - A female example of the European Kestrel (Falco tinnunculus Linn.) was shot at Strawberry Hill, near Nantucket, Mass. on Sept. 29, I887. The bird was killed by a man who was hunting for Plover at the time, and was sold with other birds to Mr. C. I. Goodale, 93 Sudbury St., Boston, where I had the pleasure of examining the specimen in the flesh shortly after it was killed. This is, I believe, the first record of its occurrence in North America. The skin is now in my cabinet.-Charles B. Cory, Boston, Mass.

Ulula cinerea in Steuben, Co., New York.-I am pleased to report the occurrence in this locality of the Great Gray Owl; a female in fine plumage was shot some five or six miles southwest of this village on the roth of last Fe'suary by a furmer who claimed it was trying to catch his 


\section{$2 \mathrm{BHL}$ Biodiversity Heritage Library}

1888. "Habits of the Purple Gallinule (Ionornis martinica)." The Auk 5, 109-110. https://doi.org/10.2307/4067371.

View This Item Online: $\underline{\text { https://www.biodiversitylibrary.org/item/55093 }}$

DOI: https://doi.org/10.2307/4067371

Permalink: https://www.biodiversitylibrary.org/partpdf/89773

\section{Holding Institution}

Smithsonian Libraries

\section{Sponsored by}

Smithsonian

\section{Copyright \& Reuse}

Copyright Status: Public domain. The BHL considers that this work is no longer under copyright protection.

This document was created from content at the Biodiversity Heritage Library, the world's largest open access digital library for biodiversity literature and archives. Visit BHL at https://www.biodiversitylibrary.org. 